\title{
Liquid Supplements for Lactating Cows Based on Liquid Streptomyces Solubles and Cane Molasses With or Without Condensed Molasses Solubles ${ }^{1,2}$
}

\author{
Paul F. Randel and Bernardo Vallejo ${ }^{3}$
}

\begin{abstract}
Four groups of 6 Holstein and Brown Swiss cows were used, 2 groups following each treatment sequence of a double-reversal experiment with three 28-day periods. Treatment A employed a liquid supplement of $80 \%$ liquid streptomyces solubles and $20 \%$ cane molasses, and treatment $\mathrm{B}$, a modification of the same to include $10 \%$ condensed molasses solubles (CMS). These were provided free choice to the groups for about 6 hours daily, and replaced an equivalent amount of solid concentrate dry matter (DM), thus reducing individual concentrate allowances, which otherwise were $1 \mathrm{~kg}$ per $2.5 \mathrm{~kg}$ of milk produced above $5 \mathrm{~kg}$ daily. At night all the animals grazed together in pastures of moderate quality. Acceptance of both liquid supplements was excellent and intakes increased throughout the experiment. Overall means (weighing period 2 data doubly) of daily DM intake from supplements $A$ and $B$ were 3.15 and $3.22 \mathrm{~kg}$. Solid concentrate allowances decreased progressively and corresponding mean intakes were only .82 and .83 kg. Milk production declined more rapidly than normal, reflecting a probable oversubstitution of liquid supplements and suboptimal intakes of digestible protein. Respective over-all weighted means for daily milk production were 11.80 and $11.65 \mathrm{~kg}$; and for milk fat percent, 4.11 and 3.99 . Various criteria of partial feed conversion efficiency, such as milk/supplemental DM, all slightly favored treatment A (ex., 3.11 vs. 2.96). Cost of total supplements/ $\mathrm{kg}$ milk was about 8 cents for each treatment. None of the differences between treatments in any of the criteria studied was significant. The addition of $10 \%$ CMS to this type of liquid supplement would be a useful method of disposal of this waste product.
\end{abstract}

\section{INTRODUCTION}

In 1978 a new liquid feed for cattle appeared on the market in Puerto Rico, based on liquid streptomyces solubles (LSS), a byproduct from the manufacture of antibiotics by a local pharmaceutical company, and cane molasses. This liquid feed has found a ready market and is now fed to several thousand head of dairy cattle. Controlled experiments to evaluate this product, which to the authors' knowledge is not fed to cattle in any other country, were lacking; such an evaluation is one objective of the present study.

Another possible ingredient for liquid feeds might be condensed molasses solubles (CMS, otherwise known as distiller's slops or stillage. This

${ }^{1}$ Manuscript submitted to Editorial Board August 27, 1980.

${ }^{2}$ Data taken from an MS thesis submitted by the junior author to the Graduate School of the Mayagüez Campus, University of Puerto Rico.

${ }^{3}$ Nutritionist, Agricultural Experiment Station, and Extension Agent, Agricultural Extension Service, Mayagüez Campus, University of Puerto Rico, respectively. 
effluent of rum manufacture is presently unused and causes serious environmental pollution. A use for at least part of the stillage needing disposal might be to incorporate it at moderate levels into the abovementioned commercial liquid feed; this experiment tested this possibility.

\section{MATERIALS AND METHODS}

Twenty-four Holstein and Brown Swiss cows in early or mid lactation from the Lajas Substation herd were distributed as equitably as possible among 4 groups, two of which were assigned to each treatment sequence of a double-reversal design experiment (5). Both experimental rations employed a liquid supplement as a partial substitute for solid concentrate. In treatment A it was a combination of approximately $80 \%$ LSS and $20 \%$ cane molasses, obtained from a commercial distributor, ${ }^{4}$ whereas in treatment $\mathrm{B}$ this mixture was modified at the substation by the addition of $10 \% \mathrm{CMS}^{5}$ The latter had a theoretical formula of $72 \% \mathrm{LSS}, 18 \%$ molasses and $10 \% \mathrm{CMS}$, but there was some variability in the proportions of LSS and molasses.

The six cows of each group had free access to their respective liquid supplements from approximately 8 am until $2 \mathrm{pm}$. During this time each group was in one of four sections of a partially paved corral, equipped with 3 liquid feeders of approximately 110-liter capacity. During late afternoon and night cows from the experiment grazed together with the rest of the milking herd (about 45 additional animals). The paddocks were of variable size, but mostly 1.5 to 3 ha. The principal herbage species were the 3 grasses star (Cynodon nlemfuensis), pangola (Digitaria decumbens) and guinea (Panicum maximum); herbage quality was moderate. A concentrate mixture, procured from a commercial source and with a guaranteed minimum of $18 \%$ crude protein (CP), was fed individually to the cows while in stanchions following morning milking. Allowances were calculated as $1 \mathrm{~kg}$ of concentrates per $2.5 \mathrm{~kg}$ of milk produced above $5 \mathrm{~kg}$ daily; from this was subtracted an amount equivalent in dry matter (DM) to that ingested from liquid supplements. For this adjustment it was necessary to assume that liquid supplement intake of each individual was equal to that of the group average.

Each of the three experimental periods lasted 28 days, divided as follows: preliminary adjustment and determination of liquid supplement intakes, 7 days; adjustment to reduced concentrate allowances, 4 days; and comparison of treatments, 17 days. Liveweights were observed once, in the morning following the last day of the experiment. Aliquot samples from two successive milkings of individual cows in each comparison

${ }^{4}$ Supplied by Torrado Solub-Mol, Inc., Hatillo, Puerto Rico.

${ }^{5}$ Supplied by Bacardí Corp., Cataño, Puerto Rico, and with approximately $58^{\circ}$ Brix. 
period were analyzed for fat content by the Babcock method (1). Specific gravity of the liquid supplements was established by weighing an exact volume of 2 liters. Dry matter content of all supplemental feeds was determined by oven drying at $80 \mathrm{C}$. Crude protein (4) and ash (1) values were determined on the dried samples.

For statistical analysis of the criteria milk yield, milk fat percent, $4 \%$ fat-corrected milk (FCM) yield, and consumption of solid concentrate, there were 24 weighted within-cow observations, ie., period $1+$ period 3 $-2 \times$ period 2 (5). There were only 4 weighted within-group observations for all criteria involving intake of liquid supplements.

\section{RESULTS AND DISCUSSIONS}

Chemical composition data (table 1) show the solid concentrate to fall slightly below its CP guarantee (18\% as fed). The high ash content of this

TABLE 1.-Chemical composition of the supplemental feeds in each period

\begin{tabular}{|c|c|c|c|c|}
\hline Feed & Dry matter & $\begin{array}{l}\text { Crude }^{1} \\
\text { protein }\end{array}$ & $\mathrm{Ash}^{1}$ & $\begin{array}{l}\text { Specific } \\
\text { gravity }\end{array}$ \\
\hline & $\%$ & $\%$ & $\%$ & $g / m l$ \\
\hline \multicolumn{5}{|c|}{ Period 1} \\
\hline Solid concentrate & 89.1 & 17.0 & 8.3 & - \\
\hline Liquid supplement A & 37.9 & 14.8 & 20.2 & 1.161 \\
\hline Liquid supplement B & 39.9 & 14.3 & 15.5 & 1.173 \\
\hline \multicolumn{5}{|c|}{ Period 2} \\
\hline Solid concentrate & 88.0 & 16.6 & 12.4 & - \\
\hline Liquid supplement A & 39.7 & 14.4 & 16.3 & 1.192 \\
\hline Liquid supplement B & 40.9 & 14.2 & 16.7 & 1.203 \\
\hline \multicolumn{5}{|c|}{ Period 3} \\
\hline Solid concentrate & 89.5 & 16.8 & 7.8 & - \\
\hline Liquid supplement A & 42.7 & 14.0 & 16.2 & 1.188 \\
\hline Liquid supplement B & 44.3 & 13.2 & 17.4 & 1.198 \\
\hline
\end{tabular}

${ }^{1}$ Dry matter basis.

feed in period 2 may reflect sampling variation, as it was inconsistent with results from the other periods. Liquid supplement B, containing $10 \%$ CMS, showed a slight advantage over $\mathrm{A}$ in DM percent and specific gravity. It also contained a higher percentage of ash in periods 2 and 3 . The high ash value of $\mathrm{A}$ in period 1 is an anomaly in the data. Higher contents of total solids, specific gravity and ash would all be expected upon addition of CMS. Conversely, a decrease in CP content would be expected, as the data indicate.

The final liveweights (mean $\pm \mathrm{SE}$ ) of groups 1 through 4 were $428 \pm$ $25,481 \pm 17,447 \pm 29$, and $456 \pm 21 \mathrm{~kg}$. The over-all mean value was 453 $\pm 12 \mathrm{~kg}$.

Mean daily intakes of DM from liquid supplements (table 2) show both 
a good initial animal acceptance and a progressive increase, especially from periods 2 to 3 . The increase with time may reflect, in part, acquired taste for these feeds, but probably it was also caused by declining consumption of concentrate. Since the latter was automatically reduced according to intake of the former, a positive feedback existed on liquid consumption. Furthermore, concentrate allowances were adjusted according to milk production, which declined with time, thus further lowering concentrate intakes. Mean daily consumptions of DM from concentrate during the 3 consecutive periods for treatments $\mathrm{A}$ and $\mathrm{B}$ were 1.57 and $1.18 ; .40$ and .82 ; and .50 and $.09 \mathrm{~kg}$. The net effect of these opposite tendencies toward increasing DM consumption from liquid supplements and decreasing DM consumption from solid concentrate was a decrease in total supplementary DM intakes from periods 1 to 2, but an increase again in period 3 (table 2).

TABLE: 2.-Mean daily dry matter intakes $(\mathrm{kg})$ from liquid supplements and from total supplements

\begin{tabular}{|c|c|c|c|c|c|c|c|c|c|}
\hline \multirow{3}{*}{ Group } & \multicolumn{9}{|c|}{ Period } \\
\hline & \multicolumn{3}{|c|}{1} & \multicolumn{3}{|c|}{2} & \multicolumn{3}{|c|}{3} \\
\hline & $\begin{array}{l}\text { Treat- } \\
\text { ment }\end{array}$ & $\begin{array}{l}\text { Liquid } \\
\text { supple- } \\
\text { ment }\end{array}$ & $\begin{array}{l}\text { Total } \\
\text { supple- } \\
\text { ments }\end{array}$ & $\begin{array}{l}\text { Treat- } \\
\text { ment }\end{array}$ & $\begin{array}{c}\text { Liquid } \\
\text { supple- } \\
\text { ment }\end{array}$ & $\begin{array}{c}\text { Total } \\
\text { supple- } \\
\text { ments }\end{array}$ & $\begin{array}{l}\text { Treat- } \\
\text { ment }\end{array}$ & $\begin{array}{l}\text { Liquid } \\
\text { supple- } \\
\text { ments }\end{array}$ & $\begin{array}{c}\text { Total } \\
\text { supple- } \\
\text { ments }\end{array}$ \\
\hline 1 & B & 2.76 & 3.93 & A & 2.76 & 3.10 & B & 4.06 & 4.09 \\
\hline 2 & A & 2.50 & 4.09 & B & 3.33 & 3.85 & A & 4.63 & 4.76 \\
\hline 3 & B & 2.84 & 4.04 & A & 3.18 & 3.63 & B & 4.16 & 4.31 \\
\hline 4 & $\mathrm{~A}$ & 2.46 & 4.01 & B & 2.64 & 3.77 & $\mathrm{~A}$ & 3.52 & 4.40 \\
\hline $2+4$ & A & 2.48 & 4.05 & B & 2.98 & 3.81 & A & 4.08 & 4.58 \\
\hline \multirow[t]{2}{*}{$1+3$} & B & 2.80 & 3.99 & A & 2.97 & 3.36 & B & 4.11 & 4.20 \\
\hline & $A-B$ & -.32 & .06 & $A-B$ & -.01 & -.45 & $A-B$ & -.03 & .38 \\
\hline
\end{tabular}

Over-all weighted means ${ }^{6}$ for treatments A and B of daily DM intake were as follows: from liquid supplements, 3.15 and $3.22 \mathrm{~kg}$; from solid concentrate, .72 and .73-kg; and from both supplements, 3.84 and $3.95 \mathrm{~kg}$. None of these differences was significant. The slightly greater intake of liquid supplement B demonstrates that addition of CMS had no adverse effect on palatability. In previous studies with lactating cows ${ }^{2,3}$ pure CMS as a liquid supplement was not consumed in amounts much beyond $1 \mathrm{~kg}$ of DM daily. This problem of low intake was non existent herein, when only $10 \%$ of CMS was used in supplement B. Mixtures of molasses and CMS gave adequate intakes when the latter formed $50 \%$ or $67 \%$, but not $87.5 \%$ of the total (3). Previous work (2) also showed that pure LSS was of problematic palatability, but in this study, additions of either $20 \%$ molasses or $20 \%$ molasses plus 10\% CMS overcame this limitation.

\footnotetext{
${ }^{6}$ Calculated by assigning double weight to the values of period 2, relative to those of periods 1 and 3 .
} 
Milk production declined sharply between periods 1 and 2 (table 3 ). This decline was steeper than would normally be expected because of advancing lactation and can be interpreted as an effect of inadequate intake of digestible protein (PD). Although the LSS-molasses mixture is a good source of digestible energy, its nitrogenous fraction is of poor digestibility (6). CMS also contributes only a moderate amount of DP (6). Therefore, under the present conditions of ad libitum intake of liquid supplements in automatic substitution for high-protein concentrate, there occurred an oversubstitution without regard for DP requirements. This emphasizes the need for proper ration balancing with high intakes of this type of liquid supplement. From periods 2 to 3 milk production declined more slowly in groups 2 and 3, whereas it recovered slightly in group 1 and more so in group 4. The latter was the most productive group throughout, while the rest were nearly equal. Over-all weighted means of

TABLE 3.-Mean daily yields (kg) of milk and $4 \%$ fat-corrected milk (FCM)

\begin{tabular}{|c|c|c|c|c|c|c|c|c|c|}
\hline \multirow{3}{*}{ Group } & \multicolumn{9}{|c|}{ Period } \\
\hline & \multicolumn{3}{|c|}{1} & \multicolumn{3}{|c|}{2} & \multicolumn{3}{|c|}{3} \\
\hline & $\begin{array}{c}\text { Treat- } \\
\text { ment }\end{array}$ & Milk & FCM & $\begin{array}{l}\text { Treat- } \\
\text { ment }\end{array}$ & Milk & FCM & $\begin{array}{c}\text { Treat- } \\
\text { ment }\end{array}$ & Milk & $\mathrm{FCM}$ \\
\hline 1 & B & 12.37 & 12.84 & A & 10.59 & 11.21 & B & 10.70 & 10.80 \\
\hline 2 & A & 12.77 & 12.98 & B & 10.95 & 10.82 & A & 10.16 & 9.56 \\
\hline 3 & B & 12.95 & 12.84 & A & 11.32 & 11.78 & B & 10.50 & 10.42 \\
\hline 4 & A & 14.28 & 13.86 & B & 12.39 & 12.06 & A & 13.34 & 12.91 \\
\hline $2+4$ & A & 13.53 & 13.42 & B & 11.67 & 11.44 & A & 11.75 & 11.24 \\
\hline \multirow[t]{2}{*}{$1+3$} & B & 12.66 & 12.84 & A & 10.95 & 11.50 & B & 10.60 & 10.61 \\
\hline & $A-B$ & .87 & .58 & $A-B$ & -.72 & .06 & $A-B$ & 1.15 & .63 \\
\hline
\end{tabular}

daily milk yield for treatments A and B were 11.80 and $11.65 \mathrm{~kg}$. This slight difference was not significant.

Mean milk fat percents for treatments A and B were as follows: period 1, 3.97 and 4.12; period 2, 4.36 and 3.88; and period 3, 3.74 and 4.06. Corresponding over-all weighted means were 4.11 and 3.99 , a not significant difference. Trends in FCM production (table 3) were generally similar to those in milk production, but with some discrepancy, viz., differences between treatments were less for FCM than for milk in periods 1 and 3 , while in period 2 treatment A slightly surpassed B in FCM. The reverse was true in milk production. Over-all weighted means in daily FCM production for treatments A and B were 11.92 and $11.58 \mathrm{~kg}$. This somewhat larger advantage of treatment A was still not significant. In summary, the adverse effect of adding $10 \%$ CMS to the liquid supplement on the productive criteria cited was only slight.

Partial feed conversion efficiencies were calculated as the ratios of supplemental DM, organic matter (OM), or CP consumed to milk or 
FCM produced. Over-all weighted means for treatments A and B were as follows: milk/DM, 3.11 and 2.96; FCM/DM, 3.18 and 2.94; milk/OM, 3.68 and 3.50; FCM/OM, 3.75 and 3.48; milk/CP, 21.0 and 20.5; and FCM/CP, 21.3 and 20.3. The criterion FCM/DM most closely approached a significant difference between treatments, giving an $\mathrm{F}$ value of 13.02 , but with only 2 degrees of freedom for error, $F .05$ is 18.51 (5). Thus, although addition of $10 \%$ CMS to the liquid supplement tended to lower partial feed efficiency, this effect was of small practical importance.

An economic assessment of the CMS addition was attempted, although this was hampered by lack of a market price for CMS, which is not sold commercially in Puerto Rico. The CMS used in this study was estimated to cost $\$ 33$. (US dollars) per metric ton for processing, as of late $1978^{7}$. This value was used, since stillage disposal is of primary importance to the rum industry, which might reasonably be expected to sell this byproduct at cost. Concurrent market prices of LSS-molasses (supplement A) and of solid concentrate were $\$ 96$. and $\$ 240$./ton, respectively. Addition of $10 \%$ CMS decreased the unit cost of liquid supplement B to $\$ 90$ / ton. Mean consumptions of supplements $\mathrm{A}$ and $\mathrm{B}$ in liquid form were 7.76 and $7.72 \mathrm{~kg}$ per day, which give daily liquid supplement costs of 77.5 and 69.5 cents. With corresponding daily solid concentrate consumptions of .81 and $.83 \mathrm{~kg}$, costs thereof were 19 and 20 cents, and daily costs of both supplements totaled 96.5 and 89.5 cents. Expressed per $\mathrm{kg}$ of milk produced, respective costs of supplementation were 8.2 and 7.7 cents. This slight difference is within the limits of errors of assumption and cannot be taken to mean that CMS utilization would reduce the cost of producing milk; but these data do suggest at least that its economic impact would not be adverse to the milk producer. Inclusion of $10 \% \mathrm{CMS}$ in liquid supplements of this type would be a useful method of disposal of rum stillage. It would provide an additional feed resource and thereby extend supplies of LSS and molasses.

\section{RESUMEN}

Se emplearon 4 grupos de 6 vacas Holstein y Pardo Suiza, 2 grupos siguiendo cada una de las secuencias de tratamientos de un experimento de diseño de reversión doble, con 3 períodos de 28 días. El tratamiento A empleó un suplemento líquido con $80 \%$ de la fracción soluble de estreptomicetos y $20 \%$ de melaza de caña, y el tratamiento B, una modificación del mismo incluyendo $10 \%$ de la fracción soluble de melaza condensada (SCM), es decir, mosto condensado de la destilación de ron. Estos se suplieron a placer a los grupos durante unas 6 horas diarias, y reemplazaron una cantidad de alimento concentrado sólido

\footnotetext{
${ }^{7}$ Information supplied by Dr. Jorge Rodríguez of Bacardi Corp.
} 
equivalente en materia seca (MS), reduciendo así a ración del concentrado, que de otro modo fueron de $1 \mathrm{~kg}$ por $2.5 \mathrm{~kg}$ de leche producida sobre los $5 \mathrm{~kg}$ diarios. De noche todos los animales pastaron en praderas de calidad módica.

La aceptación de ambos suplementos líquidos fue excelente y el consumo aumentó durante el curso de la experimentación. Las medias globales ponderadas (peso doble para datos del período 2) de consumo diario de MS en suplementos A y B fueron 3.15 y $3.22 \mathrm{~kg}$. Las raciones de concentrado sólido decrecieron progresivamente y las medias correspondientes fueron escasamente .72 y $.73 \mathrm{~kg}$.La disminucioń en la producción de leche fue más acelerada que lo normal, lo cual refleja probablemente un exceso de sustitución por suplementos líquidos y el consumo deficiente de proteína digerible. Las respectivas medias globales ponderadas de leche diaria fueron 11.80 y $11.65 \mathrm{~kg}$; y del por ciento de grasa 4.11 y 3.99. Varios criterios de eficiencia parcial de transformación del alimento, tal como leche/MS suplementaria, favorecieron levemente al tratamiento A (3.11 contra 2.96). El costo de los suplementos totales $/ \mathrm{kg}$ de leche fue aproximadamente 8 centavos con ambos tratamientos. Ninguna de las diferencias entre tratamientos en los criterios evaluados fue significativa. La inclusión de 10\% de SCM en este tipo de suplemento líquido sería un modo para deshacerse de este residuo.

\section{LITERATURE CITED}

1. Assoc. Offic. Agr. Chem., 1975. Official Methods of Analysis, 12th ed, Washington, D.C.

2. Korber, J. A. and Randel, P. F., 1978. Suplementación en vacas lecheras con LSS y mosto condensado de destilería, Proc. Ann. Tech. Meet. S.O.P.C.A. Aguadilla, Puerto Rico, Oct., 1978. (Abstr.).

3. Randel, P. F., 1979. Mosto de destilería de ron como suplemento líquido para vacas lecheras, Paper presented at VII Meet. A.L.P.A. Panamá, Sept. 1979.

4. Scales, F. M. and H. E. Harrison, 1920. Boric acid modification of the Kjeldahl method for crop and soil analysis, J. Ind. Eng. Chem. 12:350.

5. Snedecor, G. W., 1946. Statistical Methods, 4th ed, Iowa State College Press, Ames.

6. Vallejo, B, and Randel, P. F., 1980. Digestibilities of a commercial feed based on liquid streptomyces solubles and cane molasses, and of condensed molasses distiller's solubles, Submitted to J. Agr. Univ. P. R. 